\title{
EBOLA VIRUS IN WEST AFRICA AS NATIONAL SECURITY THREAT TO THE UNITED STATES OF AMERICA
}

\author{
Kemas Muhammad Zulfikar \\ Universitas Airlangga; \\ email: zulfikar.kemas@gmail.com
}

\begin{abstract}
Abstrak
Penelitian ini berusaha untuk menelaah alasan Amerika Serikat (AS) menjadikan virus Ebola yang menjadi pandemi di wilayah Afrika Barat sebagai prioritas keamanan nasional AS. Penelitian ini didasari pada fakta yang menunjukkan bahwa AS menurunkan 3.000 pasukan tentaranya ke Liberia. Selain itu, negara-negara di wilayah Afrika Barat khususnya Guinea, Sierra Leone dan Liberia sebagai negara terdampak Ebola secara geopolitik berada dalam kawasan Sahel yang sangat rentan konflik sehingga besar kemungkinannya untuk dimanfaatkan oleh kelompok teroris. Melalui kerangka berpikir keterkaitan keamanan nasional dan kebijakan luar negeri, penelitian ini akan menjelaskan alasan dibalik keputusan AS dalam menjadikan virus Ebola sebagai prioritas keamanan nasionalnya. Dengan menggunakan studi pustaka dan analisis data, penelitian ini menyimpulkan bahwa AS menjadikan Ebola sebagai prioritas keamanan nasionalnya karena AS ingin mencegah penggunaan virus Ebola untuk kegiatan bioterorisme. Hal ini dipertegas dengan penerapan strategi selective engagement $A S$ melalui penggunaan negara-negara di Afrika Barat sebagai instrumen untuk mengantisipasi bioterorisme tersebut.
\end{abstract}

Kata Kunci: $\quad$ Amerika Serikat, bioterorisme, epidemi virus Ebola, keamanan nasional, selective engagement

\begin{abstract}
This study sought to explain the reasons the United States (US) makes the Ebola virus became pandemic in West Africa as a priority of US national security. This research is shows that the US lowered its troops to 3,000 troops to Liberia. In addition, countries in the West African region in particular Guinea, Sierra Leone and Liberia as countries affected by the Ebola geopolitically located in the Sahel region highly vulnerable to conflict likely to be used by terrorist groups. Through linkages framework of national security and foreign policy, this study will explain the reasons behind the US decision in making the Ebola virus as a national security priority. By using literature and data analysis, this research concluded that the US has Ebola as a national security priority for the United States wants to prevent the use of Ebola virus for bioterrorism events. This is confirmed by the adoption of the US strategy of selective engagement through the use of the countries in West Africa as an instrument for anticipating such bioterrorism.
\end{abstract}

Keywords: bioterrorism, Ebola virus epidemic, national security, selective engagement, United States of America 


\section{Introduction}

Ebola is one of the most dangerous and deadly infectious diseases. Ebola virus disease (EVD) was first identified in 1976 found in the Democratic Republic of Congo (DRC) (Sihombing, 2014). In 2014, the issue of Ebola re-emerged in West Africa. On August $8^{\text {th }}, 2014$, WHO announced that the situation in West Africa worsened and required an international health emergency due to the Ebola epidemic in the regions. The increasing number of human victims infected Ebola virus disease causes concern throughout the world, since the virus is considered to be a humanitarian threat which remains unresolved as a national security priority. It is shown from the speech of the former President of the United States, Barrack Obama on September 16 ${ }^{\text {th }}, 2014$,

"As I've said from the start of this outbreak, I consider this a top national security priority. This is not just a matter of charity-although obviously the humanitarian toll in countries that are affected in West Africa is extraordinarily significant. This is an issue about our safety. It is also an issue with respect to the political stability and the economic stability in this region."

Ebola virus disease is currently a global pandemic, a worldwide concern, and raises the attention of many international parties. The virus, the priority of the United States national security threat, is in fact contrary to the low risk of the Ebola virus in the United States. Furthermore, the geographical position between the United States and countries infected with Ebola virus disease (EVD) in West Africa is approximately 10,700 kilometers, making it less likely that the citizens of the United States become infected with the virus. Other facts also assert that the number of citizens from West Africa coming to the United States is of small amount and rather decrease given the Ebola outbreak turning into a global issue. The Ebola epidemic as a contagious disease greatly affects the national security of a country.

Ebola virus disease as the national security priority of the United States is not only supported by the government, but also the US Congress by providing financial assistance for handling the virus, which is higher than the assistance provided for the SARS and bird flu outbreaks. The support is by far the greatest aid incurred in managing outbreaks. The attempts taken by the United States of America to be at the forefront in handling and responding to the Ebola epidemic are increasingly visible when former President Barack 
Obama and the Centers for Disease Control and Prevention (CDC) establish themselves as the pioneer through five steps: (1) surveillance; (2) outbreak response; (3) building global capacity; (4) disease eradication; and (5) applied research.

The five steps are taken to handle each infectious epidemic case including Ebola virus disease. Moreover, the involvement of the United States of America as a leader in responding to the Ebola epidemic is also apparent by the actions taken by the Department of Defense (DoD) which deployed 3,000 troops in West Africa in 2014. Besides, the United States government cooperates with the CDC and US Agency for International Development (USAID) to concentrate on reducing the number of victims affected by Ebola virus disease.

Of the aforementioned facts above, the researcher finds it intriguing that the United States of America enlist Ebola virus disease as its national security priority given the fact that countries in which the Ebola outbreak occurs are far wide apart. Therefore, the researcher would like to further explore the relationship between the disease and national security as well as to determine that security issues are not only in the form of physical threats, but also non-physical threats which indirectly affect the national security of a country.

\section{Research Method}

The researcher used qualitative method in analyzing the data collected. Upon interpreting the data, the data were, then, associated to the theories and concepts compiled in the study that the existing data were easily understood. The data were collected through literature studies and primary as well as secondary data collection. The primary data were directly collected from primary sources in the form official website. Meanwhile the secondary data were collected from literary sources, such as books, scientific journals, electronic books, mass media articles, online articles and the likes.

\section{Theoretical Framework}

\section{Relationship between National Security and Foreign Policies}

According to Collins (2014: 276), national security is a need to maintain the resilience of a nation through economic, military, and political power as well as diplomatic expertise. National security and foreign policy are interrelated; such a relation is reflected in the foreign policy issued by the nation. Security is one of the fundamental elements in 
achieving country survival that security is categorized as a vital national interest of the country. The priorities of the national security policy of the United States of America turn increasingly complex and hardly predictable, since they depend on the arena or current international condition. Sarkesian et al. (2008: 4) further explain that the national security of the United States of America prioritizes the ability of its national institutions to prevent external or internal dangers or threats aiming to disrupt the national interests of the United States (Sarkesian et al, 2008: 4).

Furthermore, Sarkesian, et al (2008: 4) assert that there is a relationship between policy, national security, and the national interests of the United States of America that is, "National security policy is primarily concerned with formulating and implementing national strategy involving the threat or use of force to create a favorable environment for US national interest." The complexity of the security-related issues leads to the United States categorizing national security priorities. This categorization aims to provide identification explanations related to threats of the state survival and the United States of America. Survival is not only limited to regional defense, but also against international terrorism, weapon proliferation as well as biological and chemical weapons.

\section{Epidemic Disease as New Security Threat}

After the end of the Cold War, military threats towards national security has significantly decreased given the increased number of non-state actors playing roles in international relations that new forms of threats emerge. These new threats do not only involve state actors, but also non-state actors, such as transnational organize crime, and others. Evans (2010: 101) explains that a potentially epidemic disease is a potential national security threat. Such a fact is proven by the greater number of victims worldwide who died due to an infectious disease of $34 \%$ compared to the victims of war of only $0.64 \%$.

Certain disease can result in an increased level of death risk to individuals which can ultimately lead to political, economic instability and class disputes. Therefore, anticipating the spread of a disease must be the main focus of the national security; especially, after the 9/11 incident as a catalyst which cast a new meaning of threats that is biological weapons as a direct threat to national security.

There are three reasons why certain disease has the potential as a bioterrorism. First, the disease is hardly diagnosable starting from the infection to the onset symptoms of the disease. Second, the capacity to spread certain disease is greater than that of an 
explosive weapon. Third, one biological weapon can produce multiplicative effects (Evans, 2010: 102). Also, certain disease can threaten both the internal and external national security of a country. Biological weapons can be a direct threat to national security due to its potential to widely and quickly spread and to reach a pandemic level that will later lead to social, political, and economic instability.

\section{Terrorism and Ebola Urgency for the United States}

The 9/11 incident became the focal point in which the before and after condition led to the emergence of the War on Terror (WoT) policy. Leffler (2003: 1048) explains that there are significant changes in the US foreign policy. Prior to the $9 / 11$ incident, the US foreign policy under the Bush administration was related to a national security strategy oriented towards resistance to the enemy by disarming or reducing the military capabilities of the enemy.

The War on Terror policy of the United States of America is also based on a grand strategy selective engagement which explains that attempts taken to improve national security and protection from conventional and unconventional threats are the fundamental national interests among the other interests of the United States of America. Art (2003: 122) defines selective engagement as a strategy which involves the political capabilities and resources of the United States in vital issues of national interest. This strategy is different from isolationist and unilateralist because selective engagement does not focus on the unilateral dominance of the United States military as well as does not withdraw the role of the United States in international relations.

In general, selective engagement consists of six prescriptions of the national interests of the United States; first, preventing the United States America from nuclear threats, biological weapons, and chemical weapons; second, preventing the occurrence of wars among the dominant countries and destructive security competitions among Eurasian countries; third, maintaining the availability and stability of oil price by securing the gulf states; fourth, maintaining the international economic order; fifth, promoting democratic order and human rights, including preventing the occurrence of genocide; and sixth, preventing and overcoming global warming (Art, 2003: 123). In practice, selective engagement is carried out through the use of US military force, the use of preventive strategies, and the use of alliances in policy instruments. 
The position of the United States of America as a major superpower country also helps create expectations that the United States is able to provide humanitarian assistance. It is supported by Singer in his book which states that each individual is obliged to provide humanitarian assistance to others if the price to be paid or incurred is minimal (Art, 2003: 125). Such a description is suitable to the current condition in West Africa, in which the Ebola virus disease causes a loss of up to 1 billion USD as calculated by the UN. The figure is indeed not a big amount for the United States, but is an exorbitant amount for countries in the West African region. They can hardly recover from the Ebola outbreak without any international assistance. Thus, the United States has the responsibility to prevent the spread of the Ebola virus disease which remains increasingly widespread and sustainable in West Africa.

\section{Discussion}

\section{Chronology of Ebola Virus Disease in West Africa}

Since the first case around March 2014, the number of cases and deaths due to EVD (Ebola Virus Disease) in West Africa continued to increase and spread throughout 2014. The spread of EVD in West Africa began in Guinea followed by the neighboring countries, such as Sierra Leone and Liberia. The most affected countries in West Africa are Guinea, Liberia and Sierra Leone given that the three countries have significantly weak health systems, human resources, and health infrastructure due to domestic conflicts and prolonged state instability. On August $8^{\text {th }}, 2014$, the WHO Director-General declared the EVD outbreak in West Africa as a Public Health Emergency of International Concern under the International Health Regulations in 2005 (Kaiser, 2015: 20).

Figure 1 The Number of Ebola Spread Cases in Various Countries

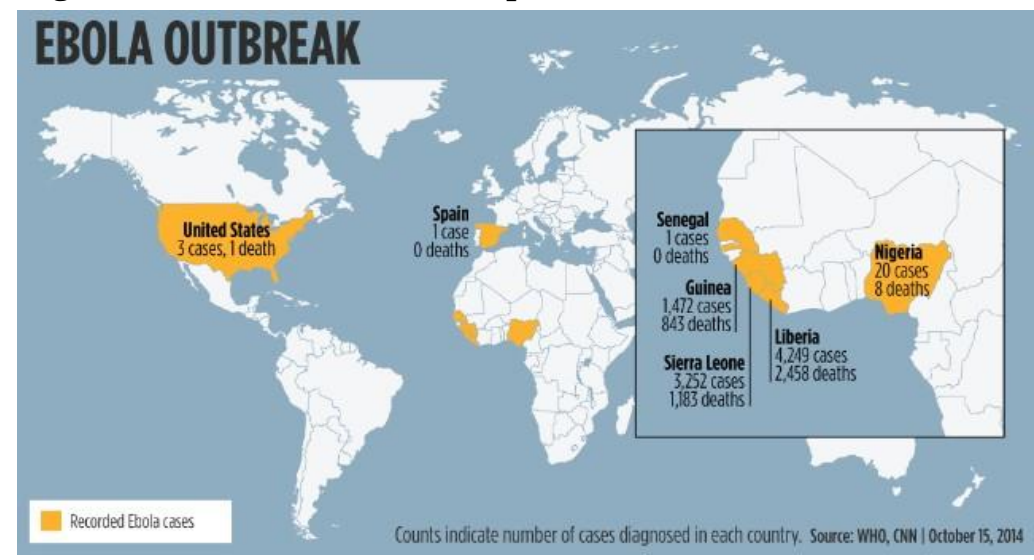

Source: (Ikhuoria, 2014: 19) 
Of the three most affected countries, Sierra Leone was ranked as the country with the highest number of 13,945 reported cases and 3,955 deaths, followed by Liberia of 4,808 deaths and of 10,672 reported cases, and Guinea, in which the EVD outbreaks began in early 2014, had a total of 3,804 reported cases and 2,534 victims (Ikhouria, 2014: 20).

The EVD outbreak phenomenon in West Africa with high number of victims has become a serious concern among the international community. The United States attempts to ignite the awareness of the international community to handle EVD which has claimed thousands of lives as quickly as possible. The accumulation of aid and positive responses from the United States and other parties is seen in the gradual decrease in reported cases and victims in Guinea, Sierra Leone and Liberia. The latest report obtained from July $5^{\text {th }}$ to October $4^{\text {th }}, 2015$ from the National Health Institution indicates that there were 848 reported cases and 51 victims, a decrease of 1,999 cases and 648 victims from the previous quarterly report (Lead Inspector General, 2015).

\section{Response of the United States on Ebola Virus Disease}

From the beginning, it can be seen that the steps taken to respond to the Ebola outbreak in West Africa had begun long before the WHO declared EVD as a Public Health Emergency of International Concern on August $8^{\text {th }}, 2014$. A month later on September $18^{\text {th }}, 2014$, the UN Security Council also declared that the Ebola outbreak in West Africa was a threat to international security and peace and the following day the UN initiated the UN Mission for Ebola Emergency Response (UNMEER), a first emergency health mission aimed at increasing coordination of responsive activities related to EVD in West Africa (Lead Inspector General, 2015). The United States as the main actor of the activities related to EVD in West Africa after the declaration of the first EVD outbreak around March 2014.

At that time, the activities conducted by the United States of America were the disease outbreak surveillance program, followed by the CDC (Centers for Disease Control and Prevention) to assist other responsive attempts and USAID (US Agency for International Development) by providing funding to WHO to help affected countries (Lead Inspector General, 2015). As an agency from the US which is responsible for overcoming all forms of disease and its prevention, the CDC also has a central role in overcoming Ebola. 
The Figure 2 below shows the distribution of technical assistance provided by the CDC to countries in West Africa affected by Ebola virus disease. The technical assistance varies depending on the risk of the country affected by the Ebola outbreak. The technical assistance includes prevention training center, building infrastructure in the context of recovery as well as financial assistance.

Figure 2 CDC Technical Assistance Recipient Countries in Africa

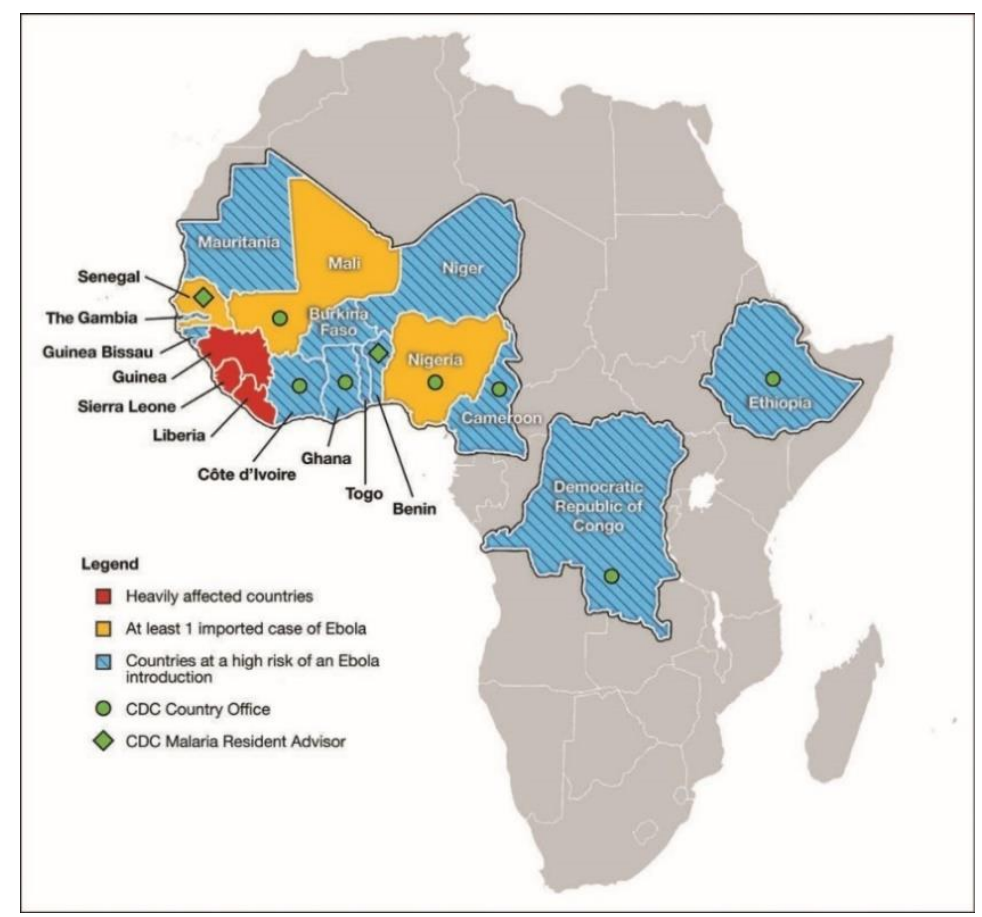

Source: Center for Disease Control and Prevention, 2016.

\section{Sahel Region and War on Terror of the United States of America in West Africa}

The potential arising for Guinea, Liberia and Sierra Leone alongside the Ebola outbreak is that the three countries would turn into failed countries given the current political, economic, and national security instability. These potentials are supported by the geopolitical position of the three countries in the conflict area (Sahel region) with a variety of radical movements or other modern crimes. Sahl or Sahel is an area in between two different geopolitical areas, in this case North Africa or White Africa and Black Africa. In the Arabic medieval era, Sahel refers to an area between Maghreb and "Bilad as Sudan" which means the country of the blacks (Taje, 2010: 25). The Sahel area as a buffer zone is a gray area which is difficult to control and is a potential source of conflict due to irresponsible parties who deliberately exploit the potential in the region for the 
sake personal interest (Taje, 2010: 25). Therefore, the Sahel region and countries in the West Africa is the potential basis of the terrorism movement.

The existence of terrorists and radical movements in the West Africa is certainly a security threat, especially for countries affected by EVD. West Africa is inseparable from terrorism, since there are various terrorist networks, such as Boko Haram in Nigeria, Mourabitounes in Mali, Ansar Al-Sunnah in Niger and the Movement for Unity and Jihad in West Africa (MUJAO) in Libya, AQIM (David, 2014). The most powerful terrorist group in West Africa is Boko Haram. Boko Haram is a genocidal criminal movement led by Islamic extremist Abubakar Shekau who has vowed to destroy every Christian school in Nigeria and to carry out terrorist attacks against Nigerian government police and government officials (START, 2014).

The Boko Haram terrorist network is spread along the coast of Africa and is affiliated with various other terrorist groups, such as Al-Shabaab in Somali, Al-Qaeda under the leadership of the Islamic Maghreb and also affiliated with ISIS in Libya; not to mention AQIM which emerges as a terrorist group that continues to expand into various regions throughout Africa of which activities threaten the neighboring countries, such as Kenya, Egypt, Tunisia, Algeria, Niger, Cameroon, and Cha. Since 2015, Boko Haram has switched to ISWAP (Islamic State of West African Provinces) which conducts terrorist activities in the West Africa.

Such a situation causes concern for other countries, both neighboring countries or other interested countries, including the United States. The potential threat of terrorism in West Africa seeks to be suppressed and prevented through integrated cooperation with the War on Terror policy of the United States. Through the collaboration, the main target to achieved is to ensure the terrorist groups cannot identify the base camp, funding, recruitment and operate in the region, as emphasized by the deputy commander of the EUCOM, General C. Wald, that at that time the United States focuses on the national security interest in Sahara and Sahel in West Africa (Obi, 2006).

\section{Ebola and Its Potential as Bioterrorism}

Global terrorists have the ability to develop biological weapons in their acts of terrorism. According to Rathore (2016), many terrorist groups currently attempt to develop chemical, biological, radiological, and nuclear weapons (Chemical Biological Radiological and Nuclear (CBRN), as these weapons are considered to be an effective 
weapon to support their terrorism activities. Rathore further adds that Al-Qaeda has attempted to obtain and develop CBRN weapons since the mid-1990s. It is proven when Al-Qaeda was led by Ayman al Zawahiri, he attempted to develop bacteria and other types of microbes to produce lethal anthrax viruses as a form of bioterrorism. Despite its failure to develop nuclear weapons as mass destruction, chances for other terrorist groups, such as ISIS to successfully develop other weapons intended to destroy the mass remain significantly high.

The use of CBRN and other various types of weapons of mass destruction are opted by ISIS due to their lack of military capability and that foreign intervention is not allowed, so the use of CBRN is considered to be the most effective to reduce foreign intervention. It is understandable that the use of CBRN is a form of weapon which can be used as a tangible threat, but its potential is latent so it needs to remain cautious (Rathore, 2016). Terrorist groups in West Africa or terrorist groups affiliated with ISIS have great potential to use Ebola as a biological weapon to cause mass damage.

According to Jones, there are several methods opted by terrorist groups in spreading Ebola as a biological weapon to the West, especially the United States. First, they infect themselves with Ebola and immediately leave West Africa for the United States before the onset symptoms turn apparent. Second, they also have the ability to insert the virus into bombs or spray devices which they can carry and transport through luggage to the United States. When the biological agent in the form of the Ebola virus arrives in the United States, it can be sprayed or exploded in crowded places. Such various scenarios are highly possible as stated by Al Shimkus, Professor of National Security Affairs at U.S Naval War College (Tornhill, 2014).

Former US President Barack Obama also states that fighting against bioterrorism like Ebola is an important case, "fighting this epidemic is a national security priority for the United States and that world leaders needed to increase efforts to counter a wide range of biological threats, from infections that are resistant to antibiotics to terrorists that seek to develop and use biological weapons" (Tornhill, 2014). The alliance between ISIS and Boko Haram also result in the increased potential of Ebola as a bioterrorism weapon. The logistical support of the two terrorist groups can be a means of launching the spread of the Ebola virus disease as a biological weapon. It is supported by one of the ISIS spokesmen stating that, "the process of spreading disease is not difficult, it is easily 
transported in a bottle in your bag and take them from Africa to America and open in an air-conditioning duct or put it in the public drinking water by elevator doors" (Alkhshali, 2015). A similar opinion was expressed by Avi, a global anti-terrorism consultant who is convinced that ISIS has military camps in several countries in West Africa and, therefore, ISIS and its allies are able to develop bioterrorism through Ebola virus disease. Besides, there is also a relationship between ISIS and several biologists that it turns way easier for ISIS to develop biological weapons.

\section{Selective Engagement of the United States in Preventing Bioterrorism in West Africa}

The US decision to make the Ebola virus a national security priority is due to the fact that the country would like to prevent the use of the virus as a bioterrorism weapon. This situation is inseparable from the US experience in responding to terrorism, especially during the 9/11 incident. After the incident, many new forms of terrorism have emerged, one of which is the use of diseases or viruses as a weapon to carry out an act of terrorism, known as bioterrorism. Such a fact is supported by the policy of The Bioterrorism Act which was officially signed by former President Bush on June $12^{\text {th }}, 2002$.

The losses incurred by EVD amounted to 32.6 billion USD by the end of 2015 and the figure can endanger the three infected countries which remain categorized as a poor country (Ameringen, 2014). From the fact, it can be seen that Ebola is an outbreak of a disease which indeed does not only threaten health, but also other sectors if not being immediately, properly, and appropriately controlled and handled. The Director-General of WHO, Margaret Chan, reveals that the Ebola epidemic threatens the survival of the community and can potentially lead to failed states. Chan also adds that such phenomenon can occur when the countries attacked by EVD are small countries which are yet to be stable in various sectors. Quick and appropriate countermeasures are needed to prevent its occurrence because failed states will result in a country being out-of-control and prone to the infiltration by radicalists and terrorist groups which has long existed in many West African regions. In terms of attempts taken related to handling Ebola virus disease, the United States of America employs the implementation of the grand strategy of US foreign policy, especially in the context of counterterrorism. The US opts for the selective engagement by involving political capabilities and resources in issues related to its 
national interests, especially national security issues. The selective engagement strategy can be seen in three ways.

The first one is the involvement of the US military force in the Ebola virus epidemic in West Africa. The military force deploys 3,000 troops to Liberia. Furthermore, the $101^{\text {st }}$ Airborne Division (Air Assault) military forces are also deployed to Liberia to deal with the increasingly massive Ebola issue. It is known that the $101^{\text {st }}$ Airborne Division military force is deployed by the US to fight ISIS, the US invasion of Iraq and Afghanistan in 2001 and 2003. It clearly indicates that the decline of US military forces to Liberia is the attempt taken by the Unites States in terms of counterterrorism due to its high potential being a biological weapon.

The second one is the preventive measures in response to the Ebola epidemic in West Africa. Such preventive actions are done by the US through domestic agencies specifying in case handling; for example, the CDC which plays a central role in overcoming Ebola through the provision of technical assistance, financial assistance, prevention training, mitigation measures, and providing health facilities and services to overcome the issue. In fact, the US also sends a DART (Disaster Assistance Response Team) to West Africa to review the latest conditions, harmonize responses among domestic agencies, and identify deficiencies in the process of handling Ebola.

The last one is one of the neighboring countries in West Africa, Liberia. The involvement of Liberia as the US entrance in implementing its counterterrorism strategies is through utilizing geopolitical aspects, since the countries affected by Ebola such as Liberia, Guinea and Sierra Leone are also close to the Sahel region. The Sahel region is a fertile ground for the emergence of terrorism in Africa. It is logical that the United States does not take any further steps, as the region is an opportunity for terrorism groups to take advantage of instability that occurs in the Ebola-affected countries as a means of developing terrorist groups through the use of bioterrorism. Basically, the West African region is a vulnerable area, prone to being invaded by terrorist and radical groups and other illegal activities, including the three countries affected by Ebola: Guinea, Sierra Leone and Liberia.

\section{Conclusions}

This study shows that the United States is the one of the most active countries in responding to the Ebola virus that occurs in West Africa, especially in the three most- 
affected countries: Liberia, Guinea, and Sierra Leone. The United States responds to the Ebola virus by issuing a policy aiming to prioritize Ebola virus as a national security threat not only because it is a social responsibility of the United States as a global leader in the international order, but also another more important factor that is the potential of Ebola being a biological weapon by terrorism in West Africa which aims to attack the United States.

Therefore, the United States counter-terrorism through a selective engagement strategy in terms of biological weapons which will be used by terrorists in West Africa. The United States prioritize Ebola virus as its national security threat and is active in tackling it to suppress the spread of the virus in West Africa even though geographically both are located wide apart. The selective engagement counter-terrorism is opted to protect the national security of the United States from terrorist threats which potentially use Ebola virus disease as a weapon to attack the United States. It places bioterrorism as the main consideration in the national security and is implemented through a selective engagement strategy by the United States of America in Liberia by deploying the $101^{\text {st }}$ Airborne Division.

Of the above discussion, several important points can be drawn. First, the spread of Ebola is massive and can threaten the national security of the United States. Therefore, several attempts were made by the US to respond to Ebola, including employing various domestic agencies which play a vital role in handling the Ebola case which has turned epidemic in West Africa. Moreover, the US also deployed 3,000 troops and the $101^{\text {st }}$ Airborne Division troops as a form of counterterrorism attempt.

Second, decreased number of troop deployment to Liberia is under particular reason, since the countries massively affected by Ebola, such as Guinea, Sierra Leone, and Liberia are also in the Sahel region. Ironically, Sahel is a gray area which is difficult to control and is the potential conflict source due to irresponsible parties who deliberately exploit the potential in the region for the sake personal interest. More specifically, the ongoing domestic instability in countries affected by the Ebola outbreak affects the increased vulnerability of the Sahel region as a basis for terrorism and Ebola as a bioterrorist weapon. It is further confirmed by the fact that West Africa has many terrorist groups, such as Boko Haram who have affiliations with global terrorism networks, such as ISIS and AQIM. 
Third, the US decision to prioritize Ebola as national security cannot be separated from the history of the US. In 2001, the US had experienced the use of anthrax as bioterrorism through the spread of anthrax spore powder carried by mail. As a result, the US issued its first bioterrorism policy through The Bioterrorism Act 2002 as the first step of the United States in responding to bioterrorism-related issues.

\section{References}

Almasy, H. A. and Steve. (2015). "ISIS leader purportedly accepts Boko Haram's pledge of allegiance." CNN. Retrieved from: http://edition.cnn.com/2015/03/12/middleeast/isis-boko-haram/ (accessed on 1 August 2019).

Ameringen, B. S. V. (2014). "Ebola, Anarchy, and Failing States: The Crisis in West Africa." Geopolitical Monitor. Retrieved from: https://www.geopoliticalmonitor.com/Ebola-anarchy-failing-states-crisis-westafrica/ (accessed on 1 August 2019).

Art, R. J. (2003). “A Grand Strategy for America." Cornell studies in security affairs 21. pp. $0-320$.

Collins, A. (2014). "Bringing communities back: Security communities and the Association of Southeast Asian Nations' plural turn." COOPERATION AND CONFLICT 49, No. 2. pp. 276-291.

David, L. (2014). "Trans-African Security: Combating Illicit Trafficking Along the Crime-Terror Continuum." U.S. Department of State.

Evans, J. (2010). "Pandemics and National Security." Global Security Studies 1, No. 1. pp. 100-109.

General, L. I. (2015). "International Ebola Response and Preparedness." Lead Inspector General Quarterly Progress Report on U.S. Government 4 .

Ikhuoria, E. (2014). "Case study: How Nigeria contained the Ebola outbreak." Nigeria Country Representative, ONE. Retrieved from: https://www.one.org/us/2014/10/29/case-study-how-nigeria-contained-the-Ebolaoutbreak/ (accessed on 1 August 2019).

Leffler, M. P. (2003). "9/11 and the Past and Future of American Foreign Policy." International Affairs 79, No. 5. pp. 1045-1063.

Obi, C. I. (2006). "Terrorism in West Africa: Real, emerging or imagined threats?" African Security Review 15, No. 3. pp. 87-101.

Rathore, S. A. (2016). "Is the Threat of ISIS Using CBRN Real?" Counter Terrorist Trends and Analysis 2, No. 12.

Sarkesian, S. C., Williams, J.A., and Cimbala, S. J. (2008). "National Security." Security 3, No. 2: pp. 1-24. Retrieved from: http://proxyau.wrlc.org/login?url=http://search.proquest.com/docview/236559009? accountid=8285 (accessed on 1 August 2019). 
Sihombing, L. (2014). "International Efforts to Overcome the Spread of Ebola" VI, No. 19. pp. $5-8$.

START. "Boko Haram Recent Attacks." National Consortium for the Study of terrorism and responses to terrorism, May (2014). pp. 1-8.

TAJE, M. (2010). "Vulnerabilities and factors of insecurity in the Sahel." the Sahl and West Africa Club Secretariat (SWAC/OECD). pp. 1-8.

The Henry J. Kaiser Family Foundation. (2015). "The U.S. Respons to Ebola : Status of the FY2015 Emergency Ebola Approriation." Retrieved from: http://kff.org/globalhealth-policy/issue-brief/the-u-s-response-to-Ebola-status-of-the-fy2015emergency-Ebola-appropriation/ (accessed on 1 August 2019).

Tornhill, T. (2014). "Could terrorists turn themselves into Ebola suicide 'bombs'? Experts fear ISIS jihadists may infect themselves to spread virus in West." Dailymail.co.uk. Retrieved from: http://www.dailymail.co.uk/news/article-2786433/Could-Ebolaused-weapon-ISIS-Terror-experts-raise-prospect-jihadists-infectin (accessed on 1 August 2019). 